\title{
Ethylene Evolution by Tomatoes Stressed by Ammonium Nutrition
}

\author{
Allen V. Barker and Kathleen M. Ready \\ Department of Plant and Soil Sciences, University of Massachusetts, Amherst, Massachusetts 01003
}

Additional index words. Lycopersicon esculentum, blossom-end rot, calcium deficiency, nitrogen nutrition, ethene

\begin{abstract}
Studies of ethylene evolution by tomato (Lycopersicon esculentum Mill.) fruit were conducted with plants receiving $\mathrm{NH}_{4}-\mathrm{N}$ or $\mathrm{NO}_{3}-\mathrm{N}$ nutrition. Fruit of plants grown with $\mathrm{NH}_{4}-\mathrm{N}$ had a higher occurrence of blossom-end rot (BER), higher $\mathrm{NH}_{4}-\mathrm{N}$ concentrations, and higher ethylene evolution rates than fruit from plants grown with $\mathrm{NO}_{3}-\mathrm{N}$. Fruit of plants grown with $\mathrm{NO}_{3}-\mathrm{N}$ showed no enhancement in ethylene evolution with BER development. Fertilizing these plants with $\mathrm{Ca}\left(\mathrm{NO}_{3}\right)_{2}$ doubled the average $\mathrm{Ca}$ concentration of fruit and restricted BER development. Ammonium suppressed Ca accumulation in fruit relative to those grown with $\mathrm{NO}_{3}-\mathrm{N}$. Ethylene evolution increased as fruit from plants receiving $\mathrm{NO}_{3}-\mathrm{N}$ ripened, but without a concomitant increase in $\mathrm{NH}_{4}-\mathrm{N}$ concentrations in the fruit. Ammonium accumulation in fruit induced BER and enhanced ethylene evolution. These relationships were unique, for $\mathrm{NH}_{4}-\mathrm{N}$ accumulation did not seem to be a naturally occurring phenomenon in ripening fruit or in fruit that have BER arising from other causal factors.
\end{abstract}

Blossom-end rot (BER) of fruit is a physiological disorder that causes extensive losses of tomato production in fields or greenhouses. Blossom-end rot has been long recognized as Ca-deficiency disorder (Evans and Troxler, 1953; Geraldson, 1957; Maynard et al., 1957), which may be induced by drought (Stout, 1934), salinity (Robbins, 1937), K fertilization (Raleigh and Chucka, 1944), $\mathrm{NH}_{4}^{+}$fertilization (Spencer and Beckenbach, 1949), and low Ca supply (Lyon et al., 1942). The form of $\mathrm{N}$ fertilization in relation to BER has been investigated considerably because of the strong restrictive effects that $\mathrm{NH}_{4}^{+}$has on cation accumulation by plants (Barker et al., 1966; Pill et al., 1978; Wilcox et al., 1973).

In agreement with other researchers (Pill and Lambeth, 1980; Pill et al., 1978; Wilcox et al., 1973), we have noted a high incidence of BER on tomatoes grown with $\mathrm{NH}_{4}-\mathrm{N}$ and have observed also that BER-affected fruit ripen more rapidly than normal fruit (unpublished data). A significant correlation between incidence of BER and uniform ripening was noted among some tomato genotypes (Trinklein and Lambeth, 1976). The phenomenon of early ripening of BER-affected fruit may be controlled endogenously by Ca levels (Rigney and Wills, 1981; Wills et al., 1977) and ethylene production in the fruit (Hoffman and Yang, 1980). Ammonium nutrition suppresses Ca accumulation by plants (Greenleaf and Adams, 1969; Pill et al., 1978), perhaps resulting in restricted $\mathrm{Ca}$ levels in fruit and advanced ripening (Rigney and Wills, 1981; Wills et al., 1977). Ethylene evolution by tomato foliage is enhanced markedly by $\mathrm{NH}_{4}{ }^{+}$toxicity (Corey et al., 1987). Perhaps the stress of $\mathrm{NH}_{4}{ }^{+}$toxicity also enhances ethylene biosynthesis by fruit. The present research investigated the relationships among $\mathrm{NH}_{4}-\mathrm{N}$ nutrition, $\mathrm{Ca}$ accumulation, and ethylene production by fruit that were damaged by BER.

\section{Materials and Methods}

This research was conducted in the spring and summer seasons in the greenhouse and field in 1990. In one experiment started in April in the greenhouse, 'Heinz 1350' tomato plants were grown

Received for publication 16 Aug. 1993. Accepted for publication 21 Dec. 1993. Contribution of the Massachusetts Agricultural Experiment Station, journal series no. 3113. The cost of publishing this paper was defrayed in part by the payment of page charges. Under postal regulations, this paper therefore must be hereby marked advertisement solely to indicate this fact. in a soil-based medium [7 sandy loam : 3 peatmoss : 2 sand (by volume) with $3 \mathrm{~g}$ limestone and $3 \mathrm{~g}$ ordinary superphosphate, $0 \mathrm{~N}-$ $8.8 \mathrm{P}-0 \mathrm{~K}$ (per liter)] in 8.5-liter plastic nursery pots $(21.5 \times 21.5$ $\mathrm{cm})$. Ten plants in each of two nutritional regimes were grown in a completely random design. One regime provided $\mathrm{N}$ nutrition from daily applications of $100 \mathrm{ml} 0.02 \mathrm{M}\left(\mathrm{NH}_{4}\right)_{2} \mathrm{SO}_{4}$ to impose $\mathrm{NH}_{4}^{+}$toxicity, as indicated by the development of BER and stem lesions (Maynard et al., 1966). Plants in the other regime were fertilized biweekly with $400 \mathrm{ml} 20 \mathrm{~N}-8.8 \mathrm{P}-16.6 \mathrm{~K}$ fertilizer (urea, ammonium phosphate, and potassium nitrate) supplying $200 \mathrm{mg}$ $\mathrm{N} /$ liter; $26 \%$ of the initial supply of $\mathrm{N}$ from this fertilizer was as $\mathrm{NO}_{3}^{-}$. Because of the inclusion of $\mathrm{NO}_{3}^{-}$in the fertilizer and likelihood of nitrification in the medium, the plants were identified as $\mathrm{NO}_{3}$-grown plants. The latter regime produced plants with no toxicity or deficiency symptoms and no BER. The fruit harvested from this experiment were used to compare ethylene evolution and $\mathrm{NH}_{4}-\mathrm{N}$ accumulation by normal and BER-affected fruit from $\mathrm{NH}_{4}$-stressed plants and normal fruit from unstressed $\left(\mathrm{NO}_{3}\right.$-grown $)$ plants. Green fruit were used in these comparisons. Preclimatric fruit such as these generally have low ethylene evolution rates (Hoffman and Yang, 1980).

In another experiment started in March, 'Vendor' tomato plants were grown in a peatmoss-vermiculite-perlite medium (peat-lite) and fertilized with the same urea, ammonium phosphate, and potassium nitrate fertilizer. None of the 10 plants in this group showed any foliar toxicity or deficiency symptoms, but BER frequency was high among the fruit. After ethylene evolution was measured in fruit from this group of plants, half of the plants was fertilized with $\mathrm{Ca}\left(\mathrm{NO}_{3}\right)_{2}$ to provide $1 \mathrm{~g} \mathrm{Ca} /$ pot (8.5-liter containers). Two weeks after fertilization, fruit were taken to determine $\mathrm{Ca}$ concentration.

In the field experiment started in May in a Hadley fine sandy loam at South Deerfield, Mass., 'Heinz 1350' plants were fertilized only with $80 \mathrm{~kg} \mathrm{~N} / \mathrm{ha}$ from $\mathrm{NH}_{4} \mathrm{NO}_{3}$ applied before planting. None of these plants showed foliar toxicity or deficiency symptoms, and none produced fruit with BER. Fruit from this experiment were used to determine ethylene evolution and $\mathrm{NH}_{4}-\mathrm{N}$ accumulation at different stages of ripening: green, $100 \%$ green; breaker, $<10 \%$ pink or red; turning, $10 \%$ to $30 \%$ tannish yellow, pink, or red; ripe, $>60 \%$ pink or red. These groupings were used because there were no differences in ethylene evolution between immature green or mature green fruit or among fruit ripened past the turning stage. 
In all experiments, ethylene was measured with whole fruit sealed in wide-mouth canning jars fitted with rubber septa in screw-top lids. Portions of the atmosphere in the jars were removed with a syringe to analyze ethylene evolution by gas chromatography (Corey et al., 1987). After ethylene evolution was determined, fruit were sectioned radially, and 10 -g portions were saved for $\mathrm{NH}_{4}-\mathrm{N}$ analysis. The remaining portions of the fruit were weighed and dried to determine dry weights for calculating $\mathrm{NH}_{4}-\mathrm{N}$ on a dryweight basis and for elemental analyses. Ammonium-N was determined volumetrically (Barker and Volk, 1964) on extracts made by homogenizing the $10 \mathrm{~g}$ of fruit in $50 \mathrm{ml}$ of $1 \mathrm{M} \mathrm{KCl}+0.02 \mathrm{M}$ $\mathrm{CuSO}_{4}$ and vacuum-filtering the homogenate. Fruit $\mathrm{pH}$ was determined electrometrically with a glass electrode and saturated calomel standard electrode on fruit juice extracted by mashing the fruit with a mortar and pestle and vacuum-filtering the resulting pulp. Calcium, $\mathrm{Mg}$, and $\mathrm{K}$ concentrations were determined by atomic absorption spectrophotometry on $1 \mathrm{M} \mathrm{HCl} \mathrm{extracts} \mathrm{of} \mathrm{the} \mathrm{dried} \mathrm{fruit}$ samples (Sahrawat, 1987). All determinations were made on at least duplicate samples of fruit taken on a given day, and replications were provided by repeating these determinations with new fruit on different days. Data were processed by analysis of variance (Steele and Torrie, 1980).

\section{Results}

Ethylene evolution and ammonium accumulation by fruit. Ethylene evolution and $\mathrm{NH}_{4}-\mathrm{N}$ accumulation are reported for green fruit with or without BER from plants receiving $\mathrm{NH}_{4}-\mathrm{N}$ nutrition and by unblemished fruit of 'Heinz 1350' plants receiving $\mathrm{NO}_{3}-\mathrm{N}$ nutrition (Fig. 1). Fruit with BER had the highest rates of ethylene evolution of the group. Fruit without BER from plants receiving $\mathrm{NH}_{4}-\mathrm{N}$ nutrition had much lower ethylene evolution but did not have $\mathrm{NH}_{4}-\mathrm{N}$ concentrations different from those of the fruit showing BER. On one occasion, $\mathrm{NH}_{4}$-grown fruit without BER at harvest developed BER after $24 \mathrm{~h}$ of storage at room temperature. None of the fruit from plants receiving $\mathrm{NO}_{3}-\mathrm{N}$ nutrition had BER, and all had low ethylene evolution rates and $\mathrm{NH}_{4}-\mathrm{N}$ accumulation relative to the fruit from plants receiving $\mathrm{NH}_{4}-\mathrm{N}$ nutrition.

'Vendor' tomatoes grown in peat-lite had high incidences of BER at the green, breaker, turning, and ripe development stages. Ethylene evolution by these fruit rose with increasing ripening stage, but there were no differences in ethylene evolution between fruit with and without BER (Fig. 2). Ammonium-N accumulation did not vary with BER condition of fruit, averaging $0.14 \mathrm{mg} \mathrm{N} / \mathrm{g}$ fresh weight in fruit with BER and $0.18 \mathrm{mg} \mathrm{N} / \mathrm{g}$ fresh weight in fruit without BER. These concentrations of $\mathrm{NH}_{4}-\mathrm{N}$ are about half of those occurring in fruit of plants grown with $\mathrm{NH}_{4}-\mathrm{N}$ (Fig. 1).

Ethylene evolution by 'Heinz 1350' tomatoes grown in the field with $\mathrm{NO}_{3}-\mathrm{N}$ increased with advancing ripening stage (Fig. 3). Ammonium-N concentrations did not vary with ripening stage, remaining at $\approx 0.15 \mathrm{mg} \mathrm{N} / \mathrm{g}$ fresh weight, essentially the same as those in 'Vendor' tomatoes.

Calcium in fruit. Calcium concentrations were higher in 'Heinz 1350 ' fruit receiving $\mathrm{NO}_{3}-\mathrm{N}$ nutrition than in fruit of plants receiving $\mathrm{NH}_{4}-\mathrm{N}$ nutrition (Table 1 ). Calcium did not differ with respect to BER incidence on the $\mathrm{NH}_{4}$-grown fruit. Concentrations of $\mathrm{Mg}$ or $\mathrm{K}$ did not vary with fruit condition or nutritional status (Table 1). With 'Vendor', Ca concentrations differed slightly but significantly whether the fruit had BER or not (Table 2). Fertilization with $\mathrm{Ca}$ increased fruit $\mathrm{Ca}$, with measurements taken 2.5 weeks after $\mathrm{Ca}$ fertilizer was applied. Blossom-end rot at this time was confined largely to ripe fruit, with very few green fruit having $\mathrm{BER}$, a result indicating that fertilization had arrested BER development. Ripe fruit had higher $\mathrm{Ca}$ than green fruit, with the increases in fruit $\mathrm{Ca}$ being restricted to fruit from fertilized plants. Neither $\mathrm{K}$ nor $\mathrm{Mg}$ varied with BER status, with an average $\mathrm{K}$ concentration of $2.57 \%$ and an average $\mathrm{Mg}$ concentration of $0.16 \%$ on a dry-weight basis.

Fruit $p H$. The juice extracted from green 'Heinz 1350' fruit with $\mathrm{NH}_{4}$-induced BER was $\mathrm{pH} 5.5$, which was higher than that ( $\mathrm{pH} 4.5$ ) from fruit of $\mathrm{NO}_{3}$-grown plants. Extracts from $\mathrm{NH}_{4}$-grown fruit without BER were $\mathrm{pH}$ 5.4. For ripening fruit with $\mathrm{NH}_{4}$-induced $\mathrm{BER}$, juice $\mathrm{pH}$ was 4.8. Juice from ripening $\mathrm{NO}_{3}$-grown fruit was $\mathrm{pH}$ 4.4.

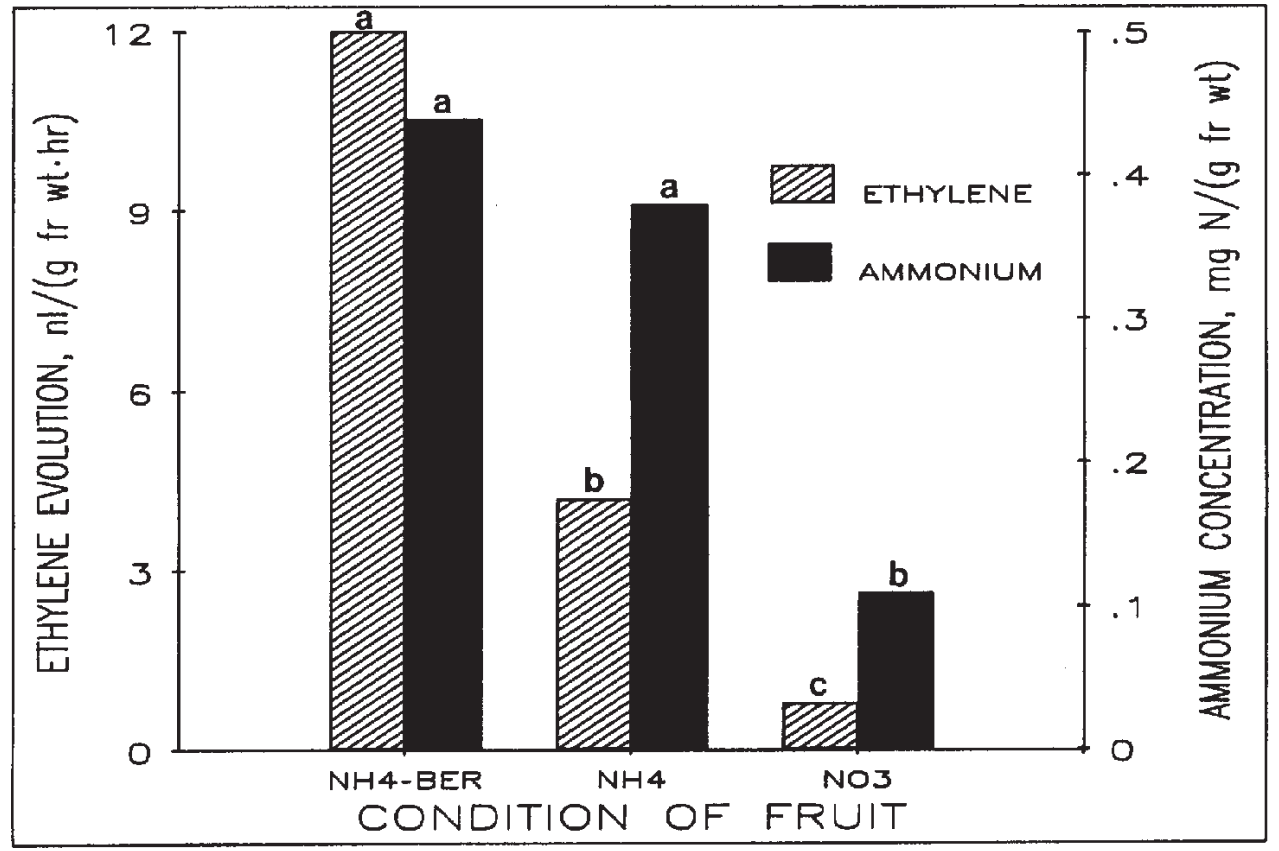

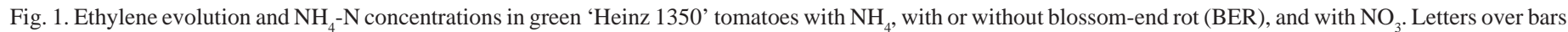
indicate significant difference by Duncan's multiple range test among means for ethylene evolution or $\mathrm{NH}_{4}-\mathrm{N}^{-}$concentration. 


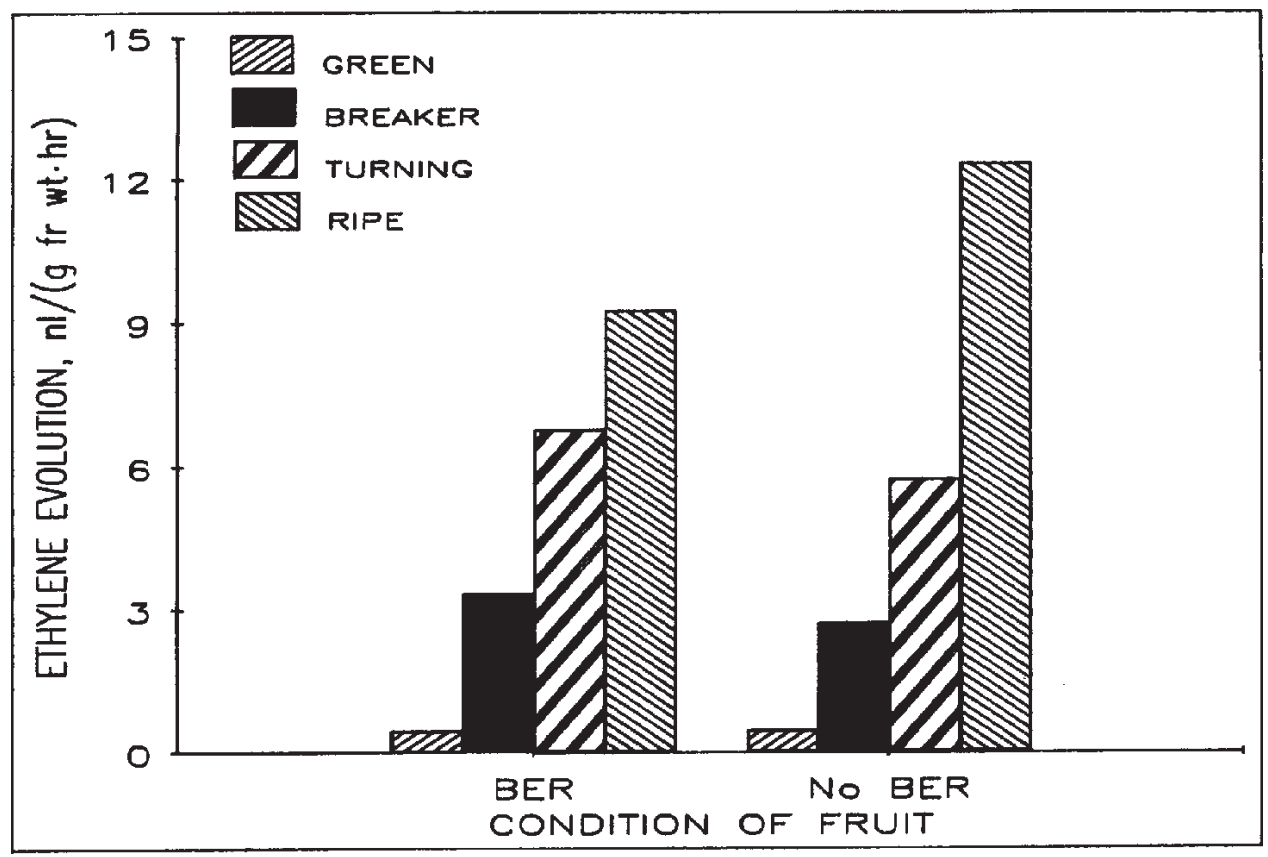

Fig. 2. Ethylene evolution of 'Vendor' tomatoes at different ripeness stages with or without blossom-end rot (BER). Results of analysis of variance: BER, nonsignificant; ripeness, significant $(P \leq 0.01)$; BER $\times$ ripeness, nonsignificant.

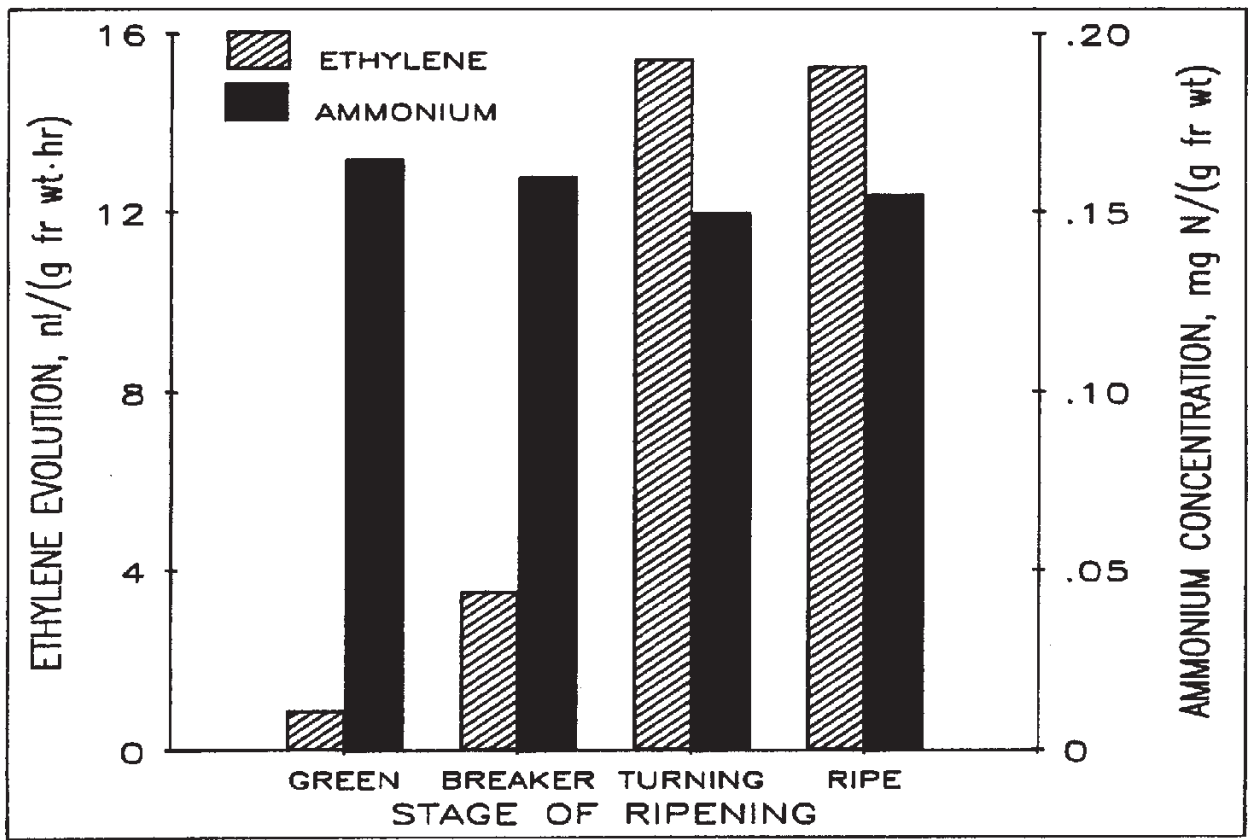

Fig. 3. Ethylene evolution and $\mathrm{NH}_{4}-\mathrm{N}$ concentrations in 'Heinz 1350' tomatoes at different ripeness stages. Results of analysis of variance: ethylene, significant increase with ripening $(P \leq 0.01) ; \mathrm{NH}_{4}-\mathrm{N}$, no change with ripening.

Table 1. Elemental composition of 'Heinz 1350' tomatoes with or without blossom-end rot (BER) from plants grown on $\mathrm{NH}_{4}-\mathrm{N}$ or $\mathrm{NO}_{3}-\mathrm{N}$ nutrition.

\begin{tabular}{|c|c|c|c|c|}
\hline \multicolumn{2}{|c|}{ Condition of fruit } & \multicolumn{3}{|c|}{ Concn $\left(\mathrm{mg} \cdot \mathrm{kg}^{-1}\right.$ dry wt) } \\
\hline $\mathrm{N}$ source & $\mathrm{BER}^{\mathrm{z}}$ & $\mathrm{Ca}$ & $\mathrm{Mg}$ & $\mathrm{K}$ \\
\hline $\mathrm{NH}_{4}$ & $\overline{B E R}$ & $390 \mathrm{a}$ & $1141 \mathrm{a}$ & $26,062 \mathrm{a}$ \\
\hline $\mathrm{NH}_{4}^{4}$ & No BER & $382 \mathrm{a}$ & $1106 \mathrm{a}$ & $25,280 \mathrm{a}$ \\
\hline $\mathrm{NO}_{3}$ & No BER & $682 \mathrm{~b}$ & $1209 \mathrm{a}$ & $25,502 \mathrm{a}$ \\
\hline
\end{tabular}

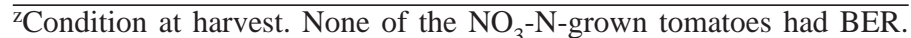
Mean separation within columns by LSD at $P \leq 0.01$.

\section{Discussion}

Plants stressed by $\mathrm{NH}_{4}-\mathrm{N}$ nutrition produced fruit with high incidences of BER. These fruit accumulated higher $\mathrm{NH}_{4}-\mathrm{N}$ concentrations, had higher ethylene evolution rates when green, and had lower $\mathrm{Ca}$ concentrations than unblemished fruit from plants receiving $\mathrm{NO}_{3}-\mathrm{N}$ nutrition. The accumulation of $\mathrm{NH}_{4}-\mathrm{N}$ was a unique characteristic of fruit from plants grown on $\mathrm{NH}_{4}-\mathrm{N}$, for neither normally ripening fruit nor BER fruit of plants receiving $\mathrm{NO}_{3}-\mathrm{N}$ showed enhanced $\mathrm{NH}_{4}-\mathrm{N}$ levels. Stresses such as $\mathrm{NH}_{4}^{+}$ toxicity (Corey et al., 1987), certain nutrient deficiencies (Feng 
Table 2. Concentrations of Ca in ripe or green 'Vendor' tomatoes with or without blossom-end rot (BER) and before or after Ca fertilization.

\begin{tabular}{|c|c|c|c|c|c|}
\hline \multirow{3}{*}{$\begin{array}{l}\text { Condition } \\
\text { of fruit } \\
\text { and means }\end{array}$} & \multicolumn{5}{|c|}{ Ca concn $\left(\mathrm{mg} \cdot \mathrm{kg}^{-1}\right.$ dry wt $)$} \\
\hline & \multicolumn{2}{|c|}{ Before fertilization } & \multicolumn{2}{|c|}{ After fertilization } & \multirow[b]{2}{*}{ Mean } \\
\hline & Green & Ripe & Green & Ripe & \\
\hline$\overline{\mathrm{BER}}$ & 625 & 563 & 1075 & 1503 & 957 \\
\hline No BER & 694 & 669 & 1162 & 1663 & $1089^{*}$ \\
\hline Mean (ripeness $\times$ fertilization) & $660 a^{z}$ & 616 a & $1118 \mathrm{~b}$ & $1583 \mathrm{c}$ & \\
\hline Mean (fertilization) & \multicolumn{2}{|c|}{669} & \multicolumn{2}{|c|}{$1377^{* * *}$} & \\
\hline
\end{tabular}

${ }_{\mathrm{z}}$ Mean separation within the ripeness $\times$ fertilization interaction by LSD at $P \leq 0.01$. BER condition $\times$ fertilization $\times$ ripeness interaction was nonsignificant.

${ }^{*}, * *$ Significant by $\mathrm{F}$ test at $P \leq 0.05$ or 0.01 , respectively.

and Barker, 1992a), and salinity (Feng and Barker, 1992b) lead to $\mathrm{NH}_{4}-\mathrm{N}$ accumulation in tomato foliage. Ammonium-N accumulation seems to be followed by ethylene evolution (Barker and Corey, 1991; Feng and Barker, 1993). With plants grown with $\mathrm{NH}_{4}-\mathrm{N}$, we noted that $\mathrm{NH}_{4}-\mathrm{N}$ accumulated in fruit without BER and that ethylene evolution was lower from these fruit than from those with BER. These observations and BER development during storage of harvested, green, $\mathrm{NH}_{4}$-grown fruit suggest that $\mathrm{NH}_{4}-\mathrm{N}$ accumulation precedes BER development and ethylene biosynthesis. Perhaps, in parallel with the physiology of foliage, $\mathrm{NH}_{4}-\mathrm{N}$ accumulation in green fruit initiates injury and processes that lead to ethylene evolution (Barker and Corey, 1991).

The finding of lower total $\mathrm{Ca}$ concentrations in $\mathrm{NH}_{4}$-grown fruit agrees with results in which $\mathrm{NH}_{4}-\mathrm{N}$ nutrition or depressed $\mathrm{Ca}$ levels were related to enhanced BER incidence (Greenleaf and Adams, 1969; Pill et al., 1978). Fruit with BER from plants grown with $\mathrm{NH}_{4}-\mathrm{N}$ had about half the $\mathrm{Ca}$ concentration of unblemished fruit from plants grown with $\mathrm{NO}_{3}-\mathrm{N}$. With plants on $\mathrm{NO}_{3}-\mathrm{N}$ nutrition, differences in fruit $\mathrm{Ca}$ concentrations were small but significant between BER and normal fruit. Although it is understood clearly (Geraldson, 1957; Maynard et al., 1957) that BER is a result of Ca deficiency, attempts to demonstrate that fact through fruit analyses have not always been successful (Murray et al., 1972; Pill and Lambeth, 1980). Differences in Ca distribution (Pill and Lambeth, 1980) or relationships of Ca with $\mathrm{K}$ and $\mathrm{Mg}$ in fruit (Murray et al., 1972) have been offered as explanations for the lack of correlation between BER and total fruit $\mathrm{Ca}$. We did not measure Ca partitioning in fruit, but observed no special relationships among $\mathrm{Ca}, \mathrm{K}$, and $\mathrm{Mg}$ in fruit with $\mathrm{BER}$, regardless of source of $\mathrm{N}$ nutrition.

Some similarities between the physiological responses of $\mathrm{NH}_{4}$-stressed fruit and bruised or diseased fruit are apparent. Bruised mature-green fruit ripened quickly and had higher ethylene evolution rates and lower titratable acidity than unblemished fruit (MacLeod et al., 1976). Ripe fruit infected with alternaria (Alternaria tenuis) or anthracnose (Colletotrtrichum coccodes) had higher $\mathrm{pH}$ and lower titratable acidity than uninfected fruit (Sapers et al., 1978). Ammonium accumulation was not measured in the previous studies; however, $\mathrm{NH}_{4}{ }^{+}$has been shown to accumulate in disease-infected leaves and to be a causal agent in the injury resulting from the infections (Bashan et al., 1980; Lovrekovich et al., 1970). The deleterious effects of bruising and disease infection may have been due to $\mathrm{NH}_{4}^{+}$accumulation induced by these injuries.

The increased ethylene evolution rates and apparently increased ripening rates by green fruit from plants grown with $\mathrm{NH}_{4}-\mathrm{N}$ seem to be the result of stresses imparted by $\mathrm{NH}_{4}-\mathrm{N}$ accumulation in the fruit. Our results show that $\mathrm{NH}_{4}-\mathrm{N}$ accumulation was confined to $\mathrm{NH}_{4}$-grown plants, was not associated with normal fruit ripening, and did not occur in fruit with BER induced by factors other than $\mathrm{NH}_{4}-\mathrm{N}$ nutrition. The results also suggest that restricted $\mathrm{Ca}$ accumulation by fruit of plants grown with $\mathrm{NH}_{4}-\mathrm{N}$ was associated with BER development.

\section{Literature Cited}

Barker, A.V. and K.A. Corey. 1991. Interrelations of ammonium toxicity and ethylene action in tomato. HortScience 26:177-180.

Barker, A.V. and R.J. Volk. 1964. Determination of ammonium, amide, amino, and nitrate nitrogen in plant extracts by a modified Kjeldahl method. Anal. Chem. 36:439-441.

Barker, A.V., R.J. Volk, and W.A. Jackson. 1966. Growth and nitrogen distribution patterns in bean plants (Phaseolus vulgaris L.) subjected to ammonium nutrition. I. Effects of carbonates and acidity control. Soil Sci. Soc. Amer. Proc. 30:228-232.

Bashan, Y., Y. Okon, and Y. Henis. 1980. Ammonia causes necrosis in tomato leaves infected with Pseudomonas tomato (Okabe) Alstatt. Physiol. Plant Pathol. 17:111-119.

Corey, K.A., A.V. Barker, and L.E. Craker. 1987. Ethylene evolution by tomato plants under stress of ammonium toxicity. HortScience 22:471473.

Evans, H.J. and R.V. Troxler. 1953. Relation of calcium nutrition to the incidence of blossom-end rot of tomatoes. Proc. Amer. Soc. Hort. Sci. 61:346-352.

Feng, J. and A.V. Barker. 1992a. Ethylene evolution and ammonium accumulation by nutrient-stressed tomato plants. J. Plant Nutr. 15:137153.

Feng, J. and A.V. Barker. 1992b. Ethylene evolution and ammonium accumulation by tomato plants under water and salinity stresses. J. Plant Nutr. 15:2471-2490.

Feng, J. and A.V. Barker. 1993. Polyamine concentration and ethylene evolution in tomato plants under nutritional stress. HortScience 28:109110.

Greenleaf, W.H. and F. Adams. 1969. Genetic control of blossom-end rot disease in tomatoes through calcium metabolism. J. Amer. Soc. Hort. Sci. 94:248-250.

Geraldson, C.M. 1957. Control of blossom-end rot of tomatoes. Proc. Amer. Soc. Hort. Sci. 69:309-317.

Hoffman, N.E. and S.F. Yang. 1980. Changes of 1-aminocyclopropane-1-carboxylic acid content in ripening fruits in relation to their ethylene production rates. J. Amer. Soc. Hort. Sci. 105:492-495.

Lovrekovich, L., H. Lovrekovich, and R.N. Goodman. 1970. Ammonia as a necrotoxin in the hypersensitive reaction caused by bacteria in tobacco leaves. Can. J. Bot. 48:167-171.

Lyon, C.B., K.C. Beeson, and M. Barrentine. 1942. Macro element nutrition of the tomato as correlated with fruitfulness and occurrence of blossom-end rot. Bot. Gaz. 103:65-667.

MacLeod, R.F., A.A. Kader, and L.L. Morris. 1976. Stimulation of ethylene and $\mathrm{CO}_{2}$ production of mature-green tomatoes by impact bruising. HortScience 11:604-606.

Maynard, D.N., W.S. Barham, and C.L. McCombs. 1957. The effect of calcium nutrition of tomatoes as related to the incidence and severity of blossom-end rot. Proc. Amer. Soc. Hort. Sci. 69:318-322. 
Murray, S.A., A.R. Murray, and K.N. Paulson. 1972. Electron probe analysis of $\mathrm{Ca}, \mathrm{Mg}$, and $\mathrm{K}$ in the fruit of the tomato, Lycopersicon esculentum, with reference to blossom-end rot. Agron. J. 64:586-588.

Pill, W.G. and V.N. Lambeth. 1980. Effects of soil water regime and nitrogen form on blossom-end rot, yield, water relations, and elemental composition of tomato. J. Amer. Soc. Hort. Sci. 105:730-734.

Pill, W.G., V.N. Lambeth, and T.M. Hinckley. 1978. Effects of nitrogen form and level on ion concentrations, water stress, and blossom-end rot incidence in tomato. J. Amer. Soc. Hort. Sci. 103:265-268.

Raleigh, G.J. and J.A. Chucka. 1944. Effects of nutrient ratio and concentrations on growth and composition of tomato plants and on the occurrence of blossom-end rot of the fruit. Plant Physiol. 19:67-678.

Rigney, C.J. and R.B.H. Wills. 1981. Calcium movement, a regulating factor in the initiation of tomato fruit ripening. HortScience 16:550-551.

Robbins, W.R. 1937. Relation of nutrient salt concentration to growth of the tomato and to the incidence of blossom-end rot of the fruit. Plant Physiol. 12:21-50.

Sahrawat, K.L. 1987. Determination of calcium, magnesium, zinc, and manganese in plant tissue using a dilute $\mathrm{HCl}$ extraction method. Com- mun. Soil Sci. Plant Anal. 18:947-962.

Sapers, G.M., J.G. Phillips, O. Panasiuk, J. Carre, A.K. Stoner, and T. Barksdale. 1978. Factors affecting the acidity of tomatoes. HortScience 13:187-189.

Spencer, E.L. and J.R. Beckenback. 1949. Blossom-end rot of tomatoes. Florida Agr. Expt. Sta. Cir. S-6.

Steele, R.G.D. and J.H. Torrie. 1980. Principles and procedures of statistics. 2nd ed. McGraw-Hill, New York.

Stout, C.J. 1934. Influence of watering treatment on the occurrence of blossom-end rot in greenhouse tomatoes. Proc. Amer. Soc. Hort. Sci. 32:515-518

Trinklein, D.H. and V.N. Lambeth. 1976. Blossom-end rot and the uniform-ripe fruit trait in tomato. HortScience 11:21-22.

Wilcox, G.E., J.E. Hoff, and C.M. Jones. 1973. Ammonium reduction of calcium and magnesium content of tomato and sweet corn leaf tissue and influence on incidence of blossom end rot of tomato fruit. J. Amer. Soc. Hort. Sci. 98:86-89.

Wills, R.B.H., S.I.H. Trimazi, and K.J. Scott. 1977. Use of calcium to delay ripening of tomatoes. HortScience 12:551-552. 